\title{
LEAF AREA INDEX DERIVED FROM HEMISPHERICAL PHOTOGRAPH AND ITS CORRELATION WITH ABOVE-GROUND FOREST BIOMASS
}

\author{
Tyas M. Basuki1,* \\ ${ }^{1}$ Forestry Research Institute for Watershed Management, Surakarta, Indonesia \\ Received: 12 April 2014, Revised: 5 March 2015, Accepted: 20 March 2015
}

\begin{abstract}
LEAF AREA INDEX DERIVED FROM HEMISPHERICAL PHOTOGRAPH AND ITS CORRELATION WITH ABOVE-GROUND FOREST BIOMASS. Leaf area index (LAI) is one of the key physical factors in the energy exchange between terrestrial ecosystem and atmosphere. It determines the photosynthesis process to produce biomass and plays an important role in performing forest stand reflectance. Therefore building relationship between LAI and biomass from field measurements can be used to develop allometric equations for biomass estimation. This paper studies the relationship between diameter at breast height $(\mathrm{DBH})$ and leaves biomass, $\mathrm{DBH}$ and crown biomass (sum up of leaves, twigs and branches) as well as between LAI and leaves biomass; LAI and crown biomass; LAI and Total Above-ground Biomass (TAGB) in East Kalimantan Province. Destructive sampling was conducted to develop allometric equations. The DBH measurements from 52 sample plots were used as training data for model development (35 plots) and for validation (17 plots). A hemispherical photograph was used to record LAI. The result shows that strong corelation ( $\mathrm{r}$ ) exists between natural logarithmic $(h) \mathrm{DBH}$ and crown biomass ranging from 0.88 to 0.98 . The correlation ( $\mathrm{r}$ ) between LAI and biomass of leaves; leaves + twigs + branches; TAGB were $0.742,0.768$ and 0.772 , respectively. Improvement of (r) between LAI and biomass can be conducted by proper time of LAI measurement, when the sky is uniformly overcast.
\end{abstract}

Keywords: LAI, biomass, hemispherical photograph, allometric equation, East Kalimantan

INDEKS LUAS DAUN (LAI YANG DIAKSES DARI FOTO HEMISPHERICALDAN KORELASINYA DENGAN PERMUKAAN BIOMASSA HUTAN. Indeks luas daun (LAI) merupakan salah satu faktor fisik utama dalam pertukaran energi antara ekosistem daratan dan atmosfer. LAI menentukan proses fotosintesis yang memproduksi biomassa dan berperan penting dalam reflektan parameter tegakan butan, oleh karena itu bubungan antara LAI dan biomassa dari pengukuran lapangan perlu dibangun untuk membentuk persamaan allometrik yang selanjutnya digunakan untuk mengestimasi biomassa di tempat lain. Tulisan ini mempelajari bubungan antara diameter setinggi dada (DBH) dengan biomassa tajuk (daun; daun + ranting + cabang) dan juga antara LAI dengan biomassa tajuk; serta LAI dengan biomassa total (TAGB). Pengambilan contoh secara destruktif dilakukan untuk, membangun persamaan allometrik. Pengukuran DBH dilakukan pada 52 plot di Kalimantan Timur dengan rincian 35 plot untuk membangun model dan 17 plot untuk. validasi. Kamera dengan lensa mata ikan digunakan untuk mengumpulkan data LAI. Hasil penelitian menunjuke.ean korelasi (r) yang tinggi antara logaritmik natural (ln) DBH dengan biomassa tajuk. berkisar antara 0,88 sampai 0,98. Koefisien korelasi ( $r$ ) antara LAI dengan biomassa daun; tajuk (daun + ranting + cabang); dan TAGB secara berurutan adalah 0,742, 0,768, dan 0,772. Peningkatan koefisien determinasi bubungan antara LAI dengan biomassa dapat ditingkatkan melalui pengukuran LAI pada waktu yang tepat yaitu kondisi langit seragam dan tidak terlalu cerah.

Kata kunci: LAI, biomasa, kamera berlensa mata ikan, persamaan alometrik, Kalimantan Timur

*Corresponding author: tmbasuki@yahoo.com 


\section{INTRODUCTION}

The method of estimating carbon can be grouped into two approaches, i.e., direct and indirect measurements. Harvesting and weighing the tree biomass is considered as a direct measurement, while indirect method or non-contact method can be conducted through satellite or airborne remote sensing (Basuki, Skidmore, van Laake, van Duren \& Hussin, 2012; Basuki, Skidmore, Hussin \& van Duren, 2013) as well as using hemispherical photography (Riaño, Valladares, Condés \& Chuvieco, 2004). The direct measurement is considered the more accurate than the non-contact method however it is time consuming and costly (Wang, Hall, Scatena, Fetcher \& Wu, 2003). The direct measurement commonly is used to validate the result obtained from indirect measurement. The biomass measurements using remote sensing techniques need more expertise on image analysis, which may cover areas from landscape level to global level (Rosenqvist, Milne, Lucas, Imhoff \& Dobson, 2003).

The non-contactmethod using hemispherical photograph or fisheye lens has been applied to estimate Leaf Area Index (LAI) and biomass by previous studies (Beckschäfer, Fehrmann, Harrison, Xu \& Kleinn, 2014; Gonsamo \& Pellika, 2008; Hanssen \& Solberg, 2007; Thimonier, Sedivy \& Schleppi, 2010). This device produces a continuous two dimensional spatial record of the canopy structure (Silbernagel \& Moeur, 2001). It can also be used to assess canopy openness, LAI and light transmittance (Hale \& Edwards, 2001). LAI assessment using hemispherical photograph is considered as tedious, however it can be used as validation for LAI measurement using satellite imageries (Morsdorf, Kötz, Meier, Itten \& Allgöwer, 2006; Sea, Cholerb, Beringerc, Weinmannd, Hutleyd \& Leuninga, 2011).

The estimation of tree biomass using the non-contact method can be performed by developing relationship between forest stand variables, such as leaf area index (LAI), diameter at breast height (DBH), crown cover, and tree height from field measurements. In this method, the reflectances of the foliage or crown closure of forests were captured by the sensors which indirectly measured the required parameters and biomass. In the case of using hemispherical photograph, the basic concept of the work is that the quantity and distribution of understory light are mainly affected by the number, size, and location of gaps in forest canopies (Frazer, Canham \& Lertzman, 1999). During the measurement the camera position was skyward, taken from forest floor with a $180^{\circ}$ fisheyes lens producing circular images which recorded the forest overstory condition (Frazer et al., 1999). Afterwards, the camera converted the images into bitmaps and the images were analyzed using a software, such as Gap Light Analyzer or GLA (Frazer et al., 1999).

LAI in broadleaf forest is defined as one sided green leaf area per unit ground area (Olivas et al., 2013; Pu, Yu, Gong \& Biging, 2005) and it is the key physical factor in the energy exchange between terrestrial ecosystem and atmosphere (Cristiano, Klein, Niklaus \& Kuenzer, 2014; Gonsamo \& Pellikka, 2008). The LAI also plays an important role in stimulating carbon and hydrological cycles (Beckschäfer et al., 2014; Olivas et al., 2013). In photosynthesis process, LAI is the driving factor to produce biomass or net primary production (Eisfelder, Klein, Niklaus \& Kuenzer, 2014). LAI also influences reflectance performances of forests (Ollinger, 2010), therefore LAI influences the physiological process and the performance of the forests.

Developing regression models between LAI and forest parameters has been carried out intensively, especially using satellite imagery. Caldararu, Palmer and Purves (2012) have assessed spatial and temporal LAI from MODIS (Moderate Resolution Imaging Spectroradiometer) imagery in tropical forest in the Eastern and Shuthern Amazon. While, Samanta et al. (2012) has studied seasonal changes of LAI in savannah and forest also in the Amazon area. In addition, Spracklen et al. (2012) have observed the correlation between precipitation and LAI derived from MODIS data. Morsdorf et al. (2006) assessed LAI using airborne laser scanning (Light Detection and 


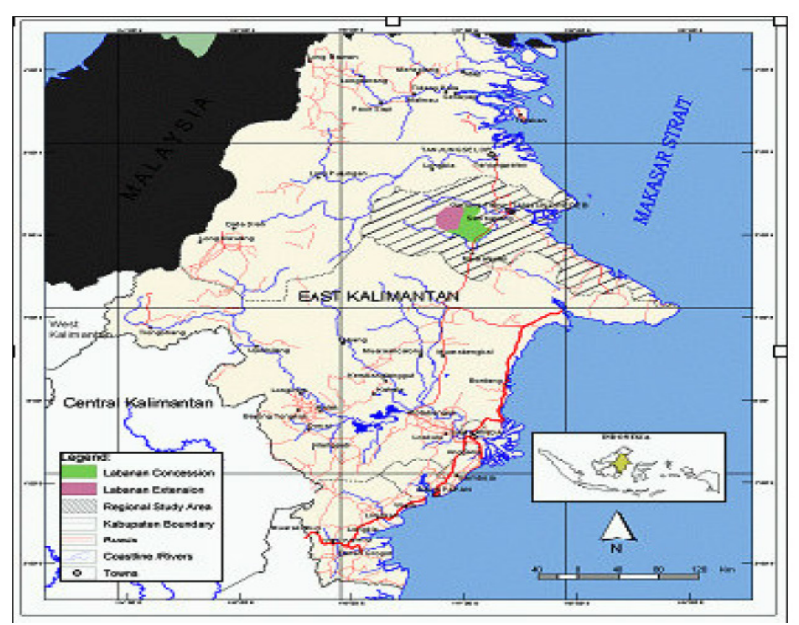

Figure 1. The situation map of the study area Source: Wahyuningrum (2006)

Ranging or LIDAR) in pine-dominated forest, while Riaño et al. (2004) compared measurement of LAI by LIDAR and hemispherical photos in broad leave forest. Based on reviewed literatures, many of the studies to assess LAI were conducted in tropical Amazonian and boreal forests. In Indonesia LAI measurement was conducted by Dietz, Hölscher, Leuschner, Malik and Amir (2007) at Montana forests in Central Sulawesi. Therefore research to measure LAI in dipterocarp forests was necessary because these forests cover large areas and they are one of the most commercialized hard wood species from South-East Asia (Basuki, van Laake, Skidmore \& Hussin, 2009).

The objective of the study was to obtain information of relationship between LAI and above-ground biomass in dipterocarp forest. This intended examination creates models that also can be useful for estimating biomass in other places having similar characteristics and may be for validating LAI measurements using other methods such as remote sensing techniques which is derived from Moderate Resolution Imaging Spectroradiometric (MODIS) LAI product.

\section{MATERIAL AND METHOD}

\section{A. The Study Area}

The study was undertaken in the Labanan forest concession area which is dominated by dipterocarp tree families with common genera of Shorea, Dipterocarpus and Vatica. The area lies between latitude $2^{\circ} 11^{\prime}$ and $2^{\circ} 20^{\prime}$ North and longitude from $116^{\circ} 55^{\prime}$ to $117^{\circ} 20^{\prime}$ East. Administratively, this concession belongs to Berau Regency, East Kalimantan Province. The map of the study area is presented in Figure 1.

\section{B. Data Collection}

Field measurements consisted of two steps, i.e. destructive sampling of tree samples (122 trees from 48 species) to develop allometric equations and forest inventory in each determined sample plot. The whole aboveground biomass except root was considered as Total Above Ground Biomass (TAGB). As explained in Basuki et al. (2009), detailed explanation of destructive sampling was conducted by separation of tree components into leaves, twigs, branches, and stem. The stems and big branches were cut in $2 \mathrm{~m}$ sections and the volume was computed. Samples were collected for every tree component and dried in laboratory to obtain moisture content. The moisture content was used to convert the fresh weight into dry weight for each tree component and summed up to obtain dry weight for the whole tree except for the root.

The allometric equation to estimate the TAGB was based on Basuki et al. (2009) namely:

$$
\ln (\mathrm{TAGB})=2.196 * \ln (\mathrm{DBH})-1.201
$$



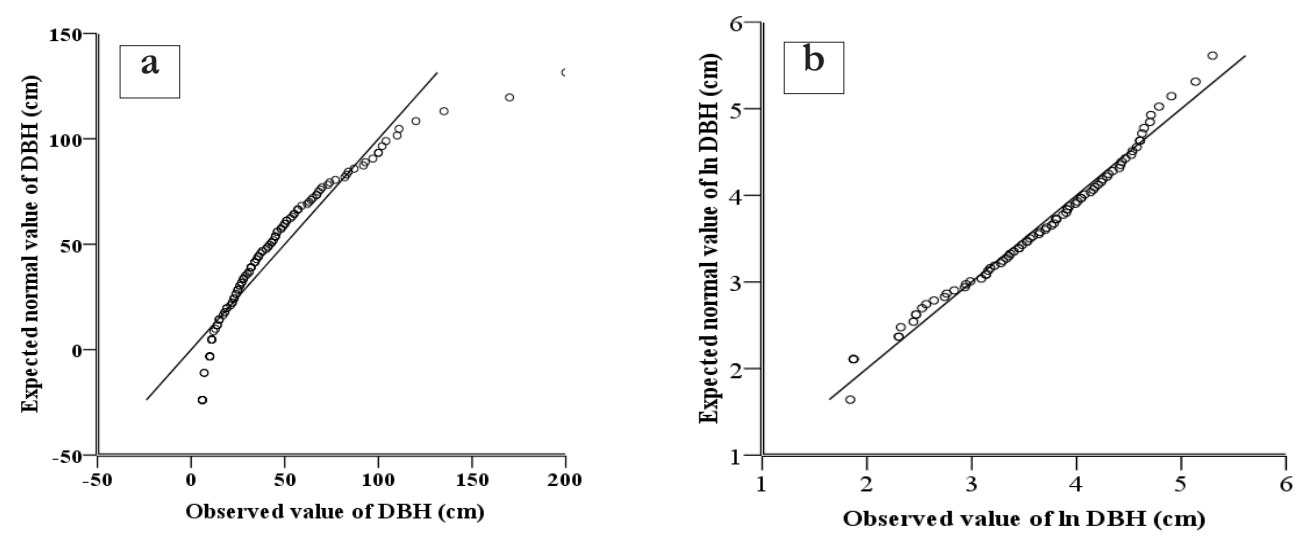

Figure 2. Distribution of DBH (cm) before (a) and after transformation (b)

where: TAGB is the total above-ground biomass in dry weight ( $\mathrm{kg} /$ tree), $\mathrm{DBH}$ is in $\mathrm{cm}$, the adjusted $\mathrm{R}^{2}$ of the model is 0.963 .

There were 52 sample plots which were distributed randomly in the study area. The size of the plot was $500 \mathrm{~m}^{2}$ in a circular shape. The radius of the plot depends on the slope of the terrain. All trees with a diameter equal or greater than $10 \mathrm{~cm}$ were measured using a diameter tape. Thirty five (35) plots were used for developing regression models and seventeen (17) plots were used for validation.

The LAI for every plot was measured using hemispherical photograph. This photograph has a 1800 field of view. Therefore, the photo provides a circular image showing a complete view in all sky directions (Jonckheere et al., 2004). The fisheye lens with sigma $8 \mathrm{~mm}$ was mounted on a Nikon camera. 400 ASA color film was used to record the trees. The camera was located at the centre of the plot under the forest canopies at $1.3 \mathrm{~m}$ height above ground level and the lens was set upward to the forest canopies (Jonckheere et al., 2005).

\section{Data Analysis}

Prior to the regression analysis, normality test of the data were conducted using Q-Q plot. The results showed that the variables were not normally distributed, therefore $\ln$ transformation was conducted. Figure 2 shows distribution of $\mathrm{DBH}$ before (a) and after $\ln$ transformation (b).
The allometric equations consist of independent variable that is the $\mathrm{DBH}$ and dependent variable which is the biomass of the tree. The components of crown consists of leaves, twigs and branches. In this study, some allometric equations were developed from destructive sampling data by building relationship between $\mathrm{DBH}$ and dry leaves biomass; DBH and dry crown biomas, as well as $\mathrm{DBH}$ and the whole tree biomass except root (TAGB). Afterwards, the resulting allometric equations were used to predict biomass of leaves and crown as well as TAGB for every plot with only DBH measured. Those estimated biomasses were then integrated with a LAI value measured by hemispherical photograph in every sample plot and used to develop new allometric equations between LAI as the independent variable and dependent variables which consisted of leaves; crown; and TAGB.

The negative films of hemispherical photos were scanned and then analyzed using Gap Light Analyzer (GLA) to obtain LAI. The manual of GLA (Frazer et al., 1999) was used as a guidance to analyze the scanned films and the LAI. According to the user manual of GLA, the first procedure to compute the LAI is loading the photo, followed by image registration. The image was registered to identify two points on the circular image to get its extent and geographic orientation. Based on these two defined points, then every pixel in the image array was converted into UTM. To obtain 
a good performance, the saturation, brightness and contrast of the photo could be adjusted.

In this research, the pixel values of less than 172 were considered as vegetation and converted to black colour. Inversely, the rest of the pixel values having values more than or equal to 172 were assigned white colour or represented the sky condition. The last action was the running of the LAI calculation. In the GLA software, the LAI were obtained from two rings. In this study the LAI values from ring 4 were used for further analysis. The LAI data were graphed to get ideas of the relationship between the independent and dependent variables. The equations with indicators of goodness of fit (adjusted $\mathrm{R}^{2}$ ) are presented in this paper.

To test the accuracy of the models, the developed allometric equations were applied to another data set which consisted of 17 plots. Afterwards, the average deviation was calculated based on Chave et al. (2005). The model with the lowest standard deviation is considered the most accurate model. The standard deviation was calculated using the formula as presented below:

$$
\overline{\mathrm{S}}(\%)=\frac{100}{\mathrm{n}} \sum_{\mathrm{i}=1}^{\mathrm{n}}|\hat{\mathrm{Y}} \mathrm{i}-\mathrm{Yi}| / \mathrm{Yi}
$$

where $\overline{\mathrm{S}}$ is the average deviation, $\mathrm{Yi}=$ the observed dry weight, $\hat{\mathrm{Y}}_{\mathrm{i}}=$ the predicted dry weight, $\mathrm{n}=$ number of observations.

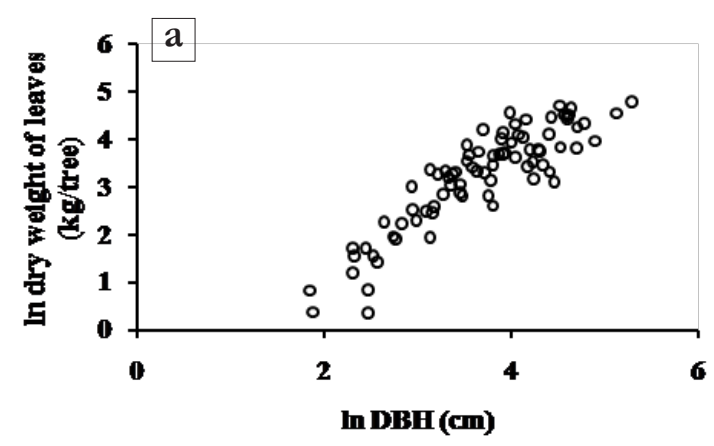

\section{RESULT AND DISCUSSION}

\section{A. Relationship between leaves, crown biomass and DBH}

Figure 3 shows the relationship between $\ln (\mathrm{DBH})$ and $\ln$ (leaves) (a), $\ln (\mathrm{DBH})$ and $\ln$ (crown) biomass. The results of the statistical analysis are presented in Table 1.

The coefficient of determination between $\mathrm{DBH}$ and leave biomasss is relatively strong in logarithmic form. The first equation consists of biomass of dry leaves and DBH, the second is crown (sum of leaves, twigs, and branches) and $\mathrm{DBH}$, and the last is TAGB (sum of leaves, twigs, branches, and stem). The coefficient of determination between $\ln$ (TAGB) and $\ln (\mathrm{DBH})$ is the highest, followed by $\mathrm{R}^{2}$ of $\ln$ (crown) and $\ln (\mathrm{DBH})$, while the lowest $\mathrm{R}^{2}$ is of $\ln$ (leaves) and $\ln (\mathrm{DBH})$.

\section{B. Relationship between LAI and biomass}

The results show that in the study area, where a selective logging was applied, the LAI ranges from 1.30 to 4.28 , with the mean of 2.59. For comparison, the study of Aragăo et al. (2005) in Amazon found that average LAI was $5.10 \pm$ 0.66 in dense primary forest which was tall with closed canopy, while in logging forest it was $4.63 \pm 0.12$. Zhang et al. (2005) also found that LAI for Douglas-Fir stand in Vancouver Island ranged from 2.3 to 4.6 and for Black spruce ranged from 2.3 to 3.2. The variation of LAI values is affected by the species composition, the development stage of vegetation and the

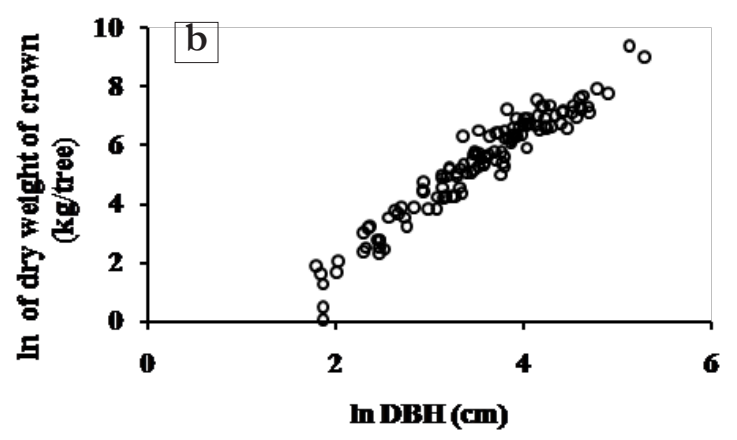

Figure 3. (a) Scatter plots of $\ln$ (leaves) and $\ln (\mathrm{DBH})$ and (b) $\ln$ (crown) and $\ln (\mathrm{DBH})$ 
Table 1. Regression analysis between leaves, crown, TAGB and DBH

\begin{tabular}{ccccc}
\hline No. & Allometric equation & Standard error & Significance & $\begin{array}{c}\text { Adjusted } \\
\mathbf{R}^{2}\end{array}$ \\
\hline 1. & $\ln ($ leaves $)=1.251 * \ln (\mathrm{DBH})-1.395$ & 0.062 & $\mathrm{p}=0.000$ & 0.77 \\
2. & $\ln ($ crown $)=2.211 * \ln (\mathrm{DBH})-2.445^{*}$ & 0.056 & $\mathrm{p}=0.000$ & 0.93 \\
3. & $\left.\ln (\mathrm{TAGB})=2.196 * \ln (\mathrm{DBH})-1.201^{*}\right)$ & 0.039 & $\mathrm{p}=0.000$ & 0.96 \\
\hline
\end{tabular}

Note: *) Crown consists of leaves, twigs, and branches, ${ }^{* *}$ Source: Basuki et al. (2009)

Table 2. Regression analysis between leaves, crown, TAGB and DBH

\begin{tabular}{cccccc}
\hline No. & Allometric equation & Standard error & Significance & r & $\begin{array}{c}\text { Adjusted } \\
\mathbf{R}^{2}\end{array}$ \\
\hline 1. & $\ln ($ leaves $)=1.612(\mathrm{LAI})^{0.084}$ & 0.023 & $\mathrm{p}=0.000$ & 0.743 & 0.538 \\
2. & $\ln ($ crown $)=3.225(\mathrm{LAI})^{0.311}$ & 0.077 & $\mathrm{p}=0.000$ & 0.768 & 0.578 \\
3. & $\ln (\mathrm{TAGB})=4.230(\mathrm{LAI})^{0.261}$ & 0.064 & $\mathrm{p}=0.000$ & 0.772 & 0.584 \\
\hline
\end{tabular}

Note: ${ }^{*}$ Crown consists of leaves, twigs, and branches, ${ }^{* *}$ Source: Basuki et al. (2009)

site condition. In addition to these natural factors, Jonckheere et al. (2004) observed that management practices and methods to measure LAI influenced the results of its values.

The relationship between the LAI and the biomasses are presented in Table 2 and the scatter plots are in Figure 4. The correlation (r) between LAI and $\ln$ (leaves), LAI and $\ln$ (crown) as well as LAI and $\ln$ (TAGB) are around 0.75 and the coefficient of determination $\left(\mathrm{R}^{2}\right)$ ranged from 0.56 to 0.57 . For comparison, the study of Dietz et al. (2007) at Montana forests in Central Sulawesi, Indonesia found that the average LAI in natural forest and forests with small timber extraction were 6.0 and 5.3, respectively. While, Khosravi, Namiranian, Ghazanfariz and Shirvani (2012) in oak forest showed that $\mathrm{R}^{2}$ between LAI and DBH, basal area, total height and crown volume were $0.36,0.36,0.45$, and 0.65 , respectively. It was inferred that there were many sources of errors, which included the applied allometric and errors in relation to LAI assessment using hemispherical photographs. The allometric equations to estimate leaves and crown as well as total biomass were built from destructive sampling of those variables and $\mathrm{DBH}$. The allometric equations have some source of error too because independent variable for leave allometric explained $77 \%$ of the dependent variable. Allometric equation for crown biomass explained $93 \%$ of the dependent variable (Table 1).

Reflectance captured by the camera could be one source of error. Based on the photo analysis, it was realized that the fisheye captured not only the foliage, but also the twigs, branches and stems (Figure $3 \mathrm{a}$ and 3c). Furthermore, when the threshold applied during the photo analysis to classify the image into sky and canopy cover, the twigs, branches and stems became dark (Figure 3b and 3d). However, there are still controversies on the effect of branches. Kucharick, Norman and Gower (1998) observed that the influence of branches on the estimation of LAI based on gap fraction analysis may be ignored, especially for fully leaved canopies due to the coverage of leaves. However, minor correction should be applied for the partially defoliated canopies. Figure 3 shows two types of crown conditions with the 

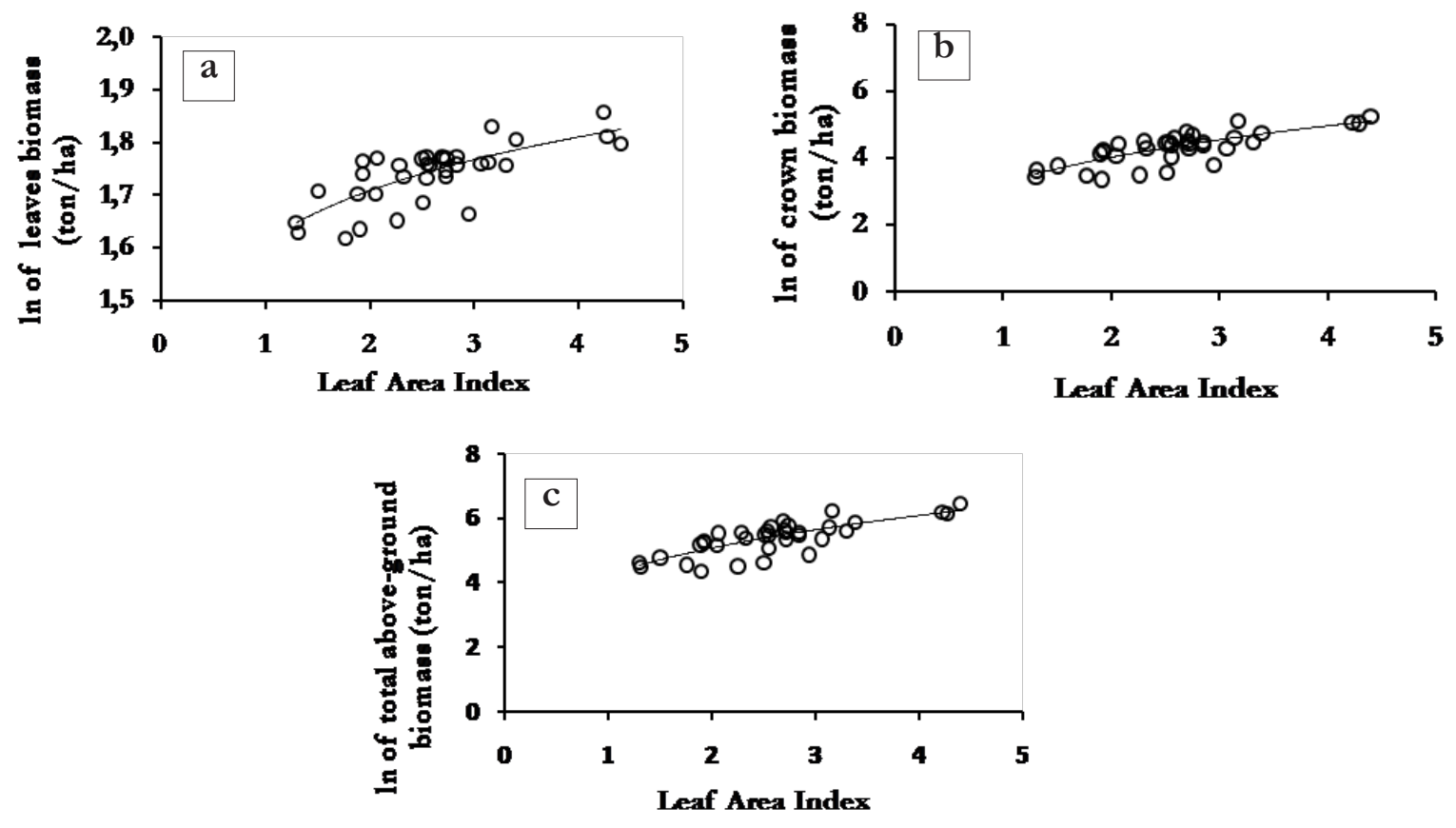

Figure 4. Scatter plots from 52 plots between $\ln$ (leaves) and LAI (a), $\ln$ (crown) and LAI (b), $\ln$ (total aboveground biomass or TAGB) and LAI (c)

estimated LAI being 2.55 (Figure 3a) and LAI being 1.87 (Figure 3c).

When the developed allometric equations were applied on the independent data set, the average deviation for the predicted leaves and crown biomass as well as TAGB were $4.5 \%$, $36.7 \%$ and $38.4 \%$, respectively. It means that the model for predicting leaves biomass is more accurate than the models for predicting crown biomass and TAGB. The sources of deviation comes from the plots that have high crown or TAGB biomass. These can be seen in Figure 4 (b and c), where the crown biomass is more than 70 ton/ha and TAGB more 200 ton/ha deviated further from 1 - 1 line than plots with crown biomass less 70 ton $\mathrm{ha}^{-1}$ and TAGB less than 200 ton $\mathrm{ha}^{-1}$. The $1-1$ line in Figure 4 is used to observe the distribution of the predicted values whether they are higher or lower than the measured ones. It can be seen that only the predicted values of leaves biomass are closer to the $1-1$ (Figure 4a) and these indicate that the predicted values are closer to the actual values. Figure $4 \mathrm{~b}$ and $\mathrm{c}$ also show that the prediction are lower than the measured biomass after 70 ton $\mathrm{ha}^{-1}$ for crown biomass and 200 ton $\mathrm{ha}^{-1}$ for the TAGB, this means that the developed allometric equations are appropriate for predictions below those values.

Based on the analysis explained above, therefore LAI measurement can be applied to predict above-ground biomass in any place having the same forest condition, without direct destructive method. Assessment of LAI using hemispherical photograph is useful for validation of LAI or biomass measurement using remote sensing. Hanssen and Solberg (2007) measured strong relationship $(r=0.96)$ between LAI derived from airborne laser scanning and log-transformed of LAI from hemispherical photograph in pine forests. In addition, on 30 plots in conifer forest Zhao et al. (2012) measured LAI derived from a ground-based scanning LIDAR and found that the values were statistically similar to those from hemispherical photos.

To obtain an accurate estimation of LAI in secondary forest, Kalacsa, S'anchez-Azofeifa, 

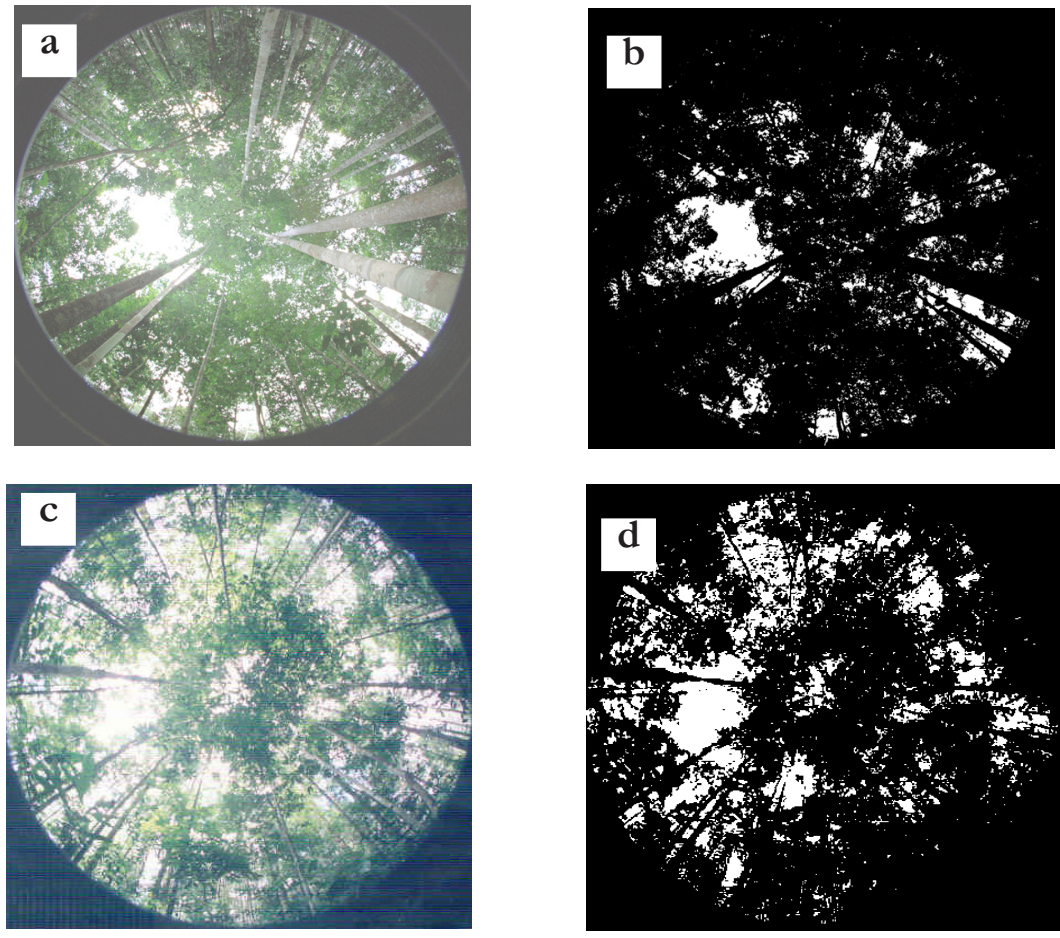

Figure 5. The crown cover captured by hemispherical photograph (a and c) and the analyzed photo after applying threshold ( $b$ and $d)$.

Notes : The estimated LAI for Figure $5 \mathrm{a}$ is 2.55 and for Figure $5 \mathrm{c}$ is 1.87
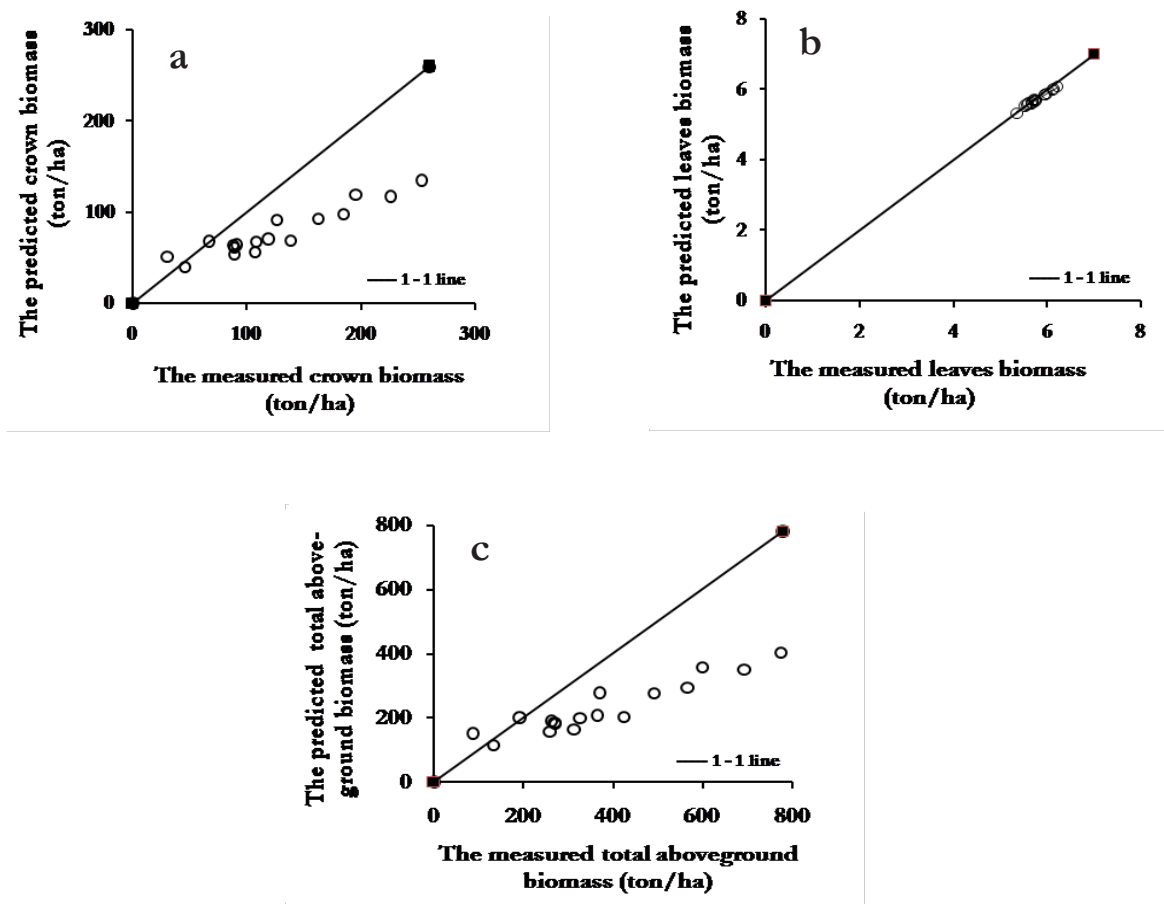

Figure 6. Distribution of the predicted leaves, crown, and total above-ground biomass around the $1-1$ line 
alvo-Alvarado, Rivard and Quesda (2005) suggested that successional stages of the forest growth should be considered. However, it is difficult to estimate LAI based on successional stages of the forests in the study area because the forests are classified as mixed forests consisting of abundant species. Besides that, the harvesting system is selective logging and the age is unkonwn, therefore the age among the trees are different and impossible to group according to successional stages.

Another way to reduce error in LAI assessment using hemispherical photograph is by considering the proper time for measurement. The measurements conducted immediately before sunrise or after sunset is a good occasion to avoid large variation of brightness across the image (Hale \& Edwards, 2002). Further suggestion is by operating the photograph beneath a uniformly overcast sky (Hale \& Edwards, 2002).

\section{CONCLUSION}

In this study, the correlation between the LAI derived from hemispherical photograph and the aboveground biomass is relatively high, about 0.77. The developed allometric equation between LAI and TAGB have been potentially very good for estimating biomass indirectly, without doing destructive sampling, for biomass less than 200 ton $\mathrm{ha}^{-1}$. The higher accuracy of LAI estimation using hemispherical photo can be obtained by a proper thresholding in differenciating the image into sky and canopy cover. The proper time of LAI measurements should be applied at a uniformly overcast sky. For further research, this study suggests to apply LAI measurement using hemispherical photographs in comparison with the estimation of LAI derived from remotely sensed data within dipterocarp forest.

\section{ACKNOWLEDGEMENT}

I would like to convey my appreciation and thanks to Bapak Ir. Dody Herika and his staffs especially mas Kirno, pak Pangut and the others for their assistance during the field campaign in the area of Labanan Forest Concession.

\section{REFERENCES}

Aragăo, L.E.O.C., Shimabukuro, Y.E., Santo, F.D.B.E., \& Williams, M. (2005). Landscape pattern and spatial variability of leaf area index in Eastern Amazonia. Forest Ecology and Management, 211, 240-256.

Basuki, T.M., Skidmore, A.K., Hussin, Y.A., \& van Duren, I. (2013). Estimating tropical forest biomass more accurately by integrating ALOS PALSAR and Landsat-7 ETM+ data. International Journal of Remote Sensing, 34(13), 4871 - 4888.

Basuki, T.M., Skidmore, A.K., van Laake, P.E., van Duren, I., \& Hussin, Y.A. (2012). The potential of spectral mixture analysis to improve the estimation accuracy of tropical forest biomass. Geocarto International, 27(4), $329-345$.

Basuki, T.M., van Laake, P.E., Skidmore, A.K., \& Hussin, Y.A. (2009). Allometric equations for estimating the above-ground biomass in tropical lowland Dipterocarp forests. Forest Ecology and Management, 257, 1684-1694.

Beckschäfer, P., Fehrmann, L., Harrison, R. D., Xu, J., \& Kleinn, C. (2014). Mapping Leaf Area Index in subtropical upland ecosystems using RapidEye imagery and the random forest algorithm. iForest, 7, 1-11. Retrieved from http://www.sisef.it/iforest/ contents/?id=ifor0968

Caldararu, S., Palmer, P.I., \& Purves, D.W. (2012). Inferring Amazon leaf demography from satellite observations of leaf area index. Biogeosciences, 9, 1389-1405.

Chave, J., Andalo, A., Brown, S., Cairns, M.A., Chambers, J.Q., Eamus, D. \& Yamakura, T. (2005). Tree allometry and improved estimation of carbon stocks and balance in tropical forests. Oceologia, 145, 87-99.

Cristiano, P.M., Madanes, N., Campanello, P.I., di Francescantonio, D., Rodríguez, S. A., Zhang, Y.J. \& Goldstein, G. (2014). High NDVI and Potential Canopy Photosynthesis of South American Subtropical Forests despite Seasonal Changes in Leaf Area Index and Air Temperature. Forests, 5(2), 287-308.

Dietz, J., Hölscher, D., Leuschner, C., Malik, A., \& Amir, M.A. (2006). Rainfall partitioning in relation to forest structure in differently 
managed montane forest stands in Central Sulawesi, Indonesia. Forest Ecology and Management, 237, 170-178.

Eisfelder, C., Klein, I., Niklaus, M., \& Kuenzer, C. (2014). Net primary productivity in Kazakhstan, its spatio-temporal patterns and relation to meteorological variables. Journal of Arid Environments, 103, 17-30.

Frazer, G.W., Canham, C.D., \&Lertzman, K.P. (1999). Gap Light Analyzer (GLA): Imaging software extract canopy structure and gap light transmission indices from true-colour fisheye photographs, users manual an program documentation. New York, USA: Simon Frases University, Burnaby, British Columbia and the Institute of Ecosystem Studies, Millbrook.

Gonsamo, A., \& Pellikka, P. (2008). Methodology comparison for slope correction in canopy leaf area index estimation using hemispherical photography. Forest Ecology and Management, 256, 749-759.

Gower, S.T., Kucharik, C.J., \& Norman, J.M. (1999). Direct and indirect estimation of leaf area index, fAPAR, and net primary production of terrestrial ecosystems. Remote Sensing Environment, 70, 29-51.

Hale, S.E., \& Edwards, C. (2002). Comparison of film and digital hemispherical photography across a wide range of canopy densities. Agricultural and Forest Meteorology, 112, 51-56.

Hanssen, K.H., \& Solberg, S. (2007). Assessment of defoliation during a pine sawfly outbreak: Calibration of airborne laser scanning data with hemispherical photograph. Forest Ecology and Management, 250, 9-16.

Jonckheere, I., Fleck, S., Nackaerts, K., Muys, B., Coppin, P., Weiss, M., \& Baret, F. (2004). Review of methods for in situ leaf area index determination Part I. Theories, sensors and hemispherical photography. Agricultural and Forest Meteorology, 121, 19-35.

Kalacska, M.E.R., S’anchez-Azofeifa, G.A., CalvoAlvarado, J.C., Rivard, B., \& Quesda, M. (2005). Effects of season and successional stage on leaf area index and spectral vegetation indices in three Mesoamerican Tropical Dry Forests. Biotropica, 37(4), 486-496.

Khosravi, S., Namiranian, M., Ghazanfariz, H., \& Shirvani, A. (2012). Estimation of leaf area index and assessment of its allometric equations in oak forests: Northern Zagros, Iran. Journal of Forest Science, 58(3), 116-122.
Kucharick, C. J., Norman, J. M., \& Gower, S. T. (1998). Measurements of branch area and adjusting leaf area index indirect measurements. Agricultural and Forest Meteorology, 91, 69-88.

Morsdorf, F., Kötz, B., Meier, E., Itten, K.I., \& Allgöwer, B. (2006). Estimation of LAI and fractional cover from small footprint airborne laser scanning data based on gap fraction. Remote Sensing of Environment, 104, 50-61.

Olivas, P.C., Oberbauer, S.F., Clark, D.B., Ryan, M.G., O’Brien, J.J., \& Ordoñez, H. (2013). Comparison of direct and indirect methods for assessing leaf area index across a tropical rain forest landscape. Agricultural and Forest Meteorology, 177, 110 - 116.

Ollinger, S.V. (2011). Sources of variability in canopy reflectance and the convergent properties of plants. New Phytologist, 189, 375-394.

Pu, R., Yu, Q., Gong, P., \& Biging, G. S. (2005). EO-1 Hyperion, ALI and Landsat 7 ETM+ data comaparison for estimating forest crown closure and leaf area index. International Journal of Remote Sensing, 26(3), 457-474.

Riaño, D., Valladares, F., Condés, S., \& Chuvieco, E. (2004). Estimation of leaf area index and covered ground from airborne laser scanner (Lidar) in two contrasting forests. Agricultural and Forest Meteorology, 124, 269-275.

Rosenqvist, A., Milne, A., Lucas, R., Imhoff, M., \& Dobson, C. (2003). A review of remote sensing technology in support of the Kyoto Protocol. Environmental Science \& Policy, 6, 441-455.

Samanta, A., Knyazikhin, Y., Xu, L., Dickinson, R. E., Fu, R., Costa, M. H., ... Myneni, R. B. (2012). Seasonal changes in leaf area of Amazon forests from leaf flushing and abscission. Journal of Geophysical Research, 117, $1-13$.

Sea, W.B., Cholerb, P., Beringerc, J., Weinmannd, R.A., Hutleyd, L.B., \& Leuninga, R. (2011). Documenting improvement in leaf area index estimates from MODIS using hemispherical photos for Australian savannas. Agricultural and Forest Meteorology, 151, 1453- 1461.

Silbernagel, J., \& Moeur, M. (2001). Modeling canopy openness and understorey gap patters based on image analysis and mapped tree data. Forest Ecology and Management, 149, 217-233.

Spracklen, D.V., Arnold, S.R., \& Taylor, C.M. (2012). Observations of increased tropical rainfall preceded by air passage over forests. Nature, 
489, $282-286$

Thimonier, A., Sedivy, I., \& Schleppi, P. (2010). Estimating leaf area index in different types of mature forest stands in Switzerland: a comparison of methods. European Journal of Forest Resources, 129, 543-562. doi:10.1007/ s10342-009-0353-8

Wahyuningrum, N. (2005). Foliage biomass estimation in tropical logged over forest East Kalimantan, Indonesia (Master Thesis) (p. 54). Enschede: ITC.

Wang, H., Hall, C.A.S., Scatena, F.N., Fetcher, N., \& Wu, W. (2003). Modelling the spatial and temporal variability in climate and primary productivity across the Luquillo Mountains, Puerto Rico. Forest Ecology and Management, 179, 69-94.

Zhang, Y., Chen, J.M., \& Miller, J.R. (2005). Determining digital hemispherical photograph exposure for leaf area index estimation. Agricultural and Forest Meteorology, 133, 166-181.

Zhao, F., Strahler, A.H., Schaaf, C.L., Yao, T., Yang, X., Wang, Z., Newnham, G. J. (2012). Measuring gap fraction, element clumping index and LAI in Sierra Forest stands using a full-waveform ground-based lidar. Remote Sensing of Environment, 125, 73-79. 